\title{
Effects of Teacher and Peer Mediation on Students' Self-Efficacy Belief About Their Extensive Reading Practice: In Case of Asossa Preparatory School
}

\author{
Melaku Ensermu Chaka \\ Wollega University, Institute of Language Studies and Journalism, Department of English Language and \\ Literature \\ Tamene Kitila \\ Addis Ababa University, College of Humanities, Language Studies, Journalism and Communication. \\ Department of Foreign Languages and Literature. ( second author) \\ Sherif Ali \\ Wollega University, Institute of Language Studies and Journalism, Department of English Language and \\ Literature
}

\begin{abstract}
This study investigated the EFL students' self-efficacy belief about extensive reading through mediated teaching reading mode. The study employed a quasi-experimental design. Two intact grade 11 classes were purposively selected and randomly assigned into experimental $(\mathrm{N}=30)$ and control $(\mathrm{N}=30)$ group. Five capable peers were selected from the experimental group along with their EFL teacher to serve as mediators while this was not done in the control group. Pre-intervention questionnaire and pre-test were administered to both groups to see if they had the same self-efficacy belief about extensive reading and the ability in reading. The groups were also given a post-intervention questionnaire and post reading test to determine the extent students become positive selfefficacious and their reading skill was improved. SPSS 20 was used to analyze the collected data. From independent sample test, pre-intervention questionnaire and pre-test results indicated that both group students held similar perceived self-efficacy belief about extensive reading and had similar ability in reading skills. Whereas the paired sample t-test proved that there was a significant mean score difference within the experimental group students, but there was no within the control group. The study concluded that the intervention positively changed the students' self-efficacy belief about extensive and improved their reading skill. It was recommended that EFL teacher need to play effective role in mediating students to raise their self-efficacy belief through extensive reading. Similarly, using more capable peers was an important measure in supporting peer learners.
\end{abstract}

Keywords: extensive reading, self-efficacy belief, mediation

DOI: $10.7176 /$ RHSS/10-19-03

Publication date:October $31^{\text {st }} 2020$

\section{Introduction}

English is among the popular subjects taught as a second or a foreign language in the world. It plays a multiple of role in different disciplines including education across the countries of the world (Tamrackitkun, 2010). In cognizant of the widely growing status of English, Ethiopia has incorporated it into the curriculum of the school at all levels ( MOE, 1994; 2004). Currently, the country also emphasized teaching of reading and writing at preparatory school level, grade 11 and 12 (MOE,2008). These students were expected to have adequate reading skill in the target language. The primary reason was that English is required for entry into the tertiary level of education (MOE, 2008), where the students have more exposure to reading to study all the subjects they would be offered in English as a medium of instruction. Reading, which this study focused on, affects students' academic achievement both in English as a subject itself and in other academic subject areas since the students study these subjects through reading.

Similarly, students' self-efficacy belief (SEB) affects their reading skill. Students' success or failure relays on the self-efficacy belief they hold about reading. Bodies of definitions were given to self-efficacy belief. For instance, self-efficacy belief is ones personal decision to accept or reject some course of action or skill in learning (Bandura, 1997). Extending Bandura's (ibid) definition, Naseri (2012) forwarded his definition as self-efficacy belief is a factor that affects students' capabilities to act on their learning tasks in a specific area, for example reading. Literature also notes that self-efficacy belief is one's ability to successfully perform a task (Brittany, 2017). Pajares(2002), Boakye( 2015) and Tobing ( 2013) confirm the above ideas. Based on these definitions, selfefficacy belief is viewed as individual students' beliefs, abilities and actions to organize and execute courses of action in learning reading.

In connection to learning reading, extensive reading (ER) plays a pivotal role. It is defined as "sustained silent 
reading" (Powell, 2005), "free voluntary reading, pleasure reading" (Krashen, 2004) and "abundant reading" (Day and Bamford, 1998). Extensive reading is also mean learner's exposure to massive interesting and interactive reading materials (Nation, 2009; Harmer, nd; Brown, 2007) such as news papers, magazines, novels, short stories, and journals. The students read these supplementary materials for general understanding. ER provides the students with variety of gains: vocabulary knowledge, sentence structure, language fluency, grammar, speaking and listening. Also, ER increases students' reading self-efficacy belief, their liking of reading ( Nuttal, 1996). As a result, the students build positive self-efficacy belief in themselves by which they further develop their reading ability. In this regard, However, Asossa preparatory school students in Benishangul Gumuz region, Ethiopia, fail to experience ER. They were with low level of self-efficacy belief about reading. In addition, EFL teachers merely seem to employ intensive reading strategy (only limited to textbook reading) to teach reading. In order to alleviate such shortcomings, mediating students' learning reading was mandatory. The mediated learning reading facilitates learning to read, encourages learners to read, to think critically, to solve problems, to tackle the learning material and the task, to bring change in the students' self-efficacy belief, and in cognitive development (Ferestein, 1990). Teacher and capable peers were mediators (as combined effect), while students were mediatees. The mediators intervene between the problem the students encounter in learning reading and the reading task and/or textbook to provide students with meaningful support. For instance, if the student's answer to the question "What is the main idea if the third paragraph?" The mediator again asks the student eliciting question as "Have you seen it in this way (...xyz..)? This triggers the students to find solution to problem through trying out, i.e, a belief in positive outcomes (one of the mediation criteria). To this effect, the study used Ferestein's (1990) mediation criteria of learning which he termed it as Mediated Learning Exlerience (MLE). The study also empoyed Vygotsky's cognitive development, social interaction and Bandura's $(1977,1997)$ social cognitive theory. All these psychologists advocate social learning, therefore, the study employed social constractivism philosophy.

The purpose of this study was to investigate whether or not teacher and peer mediation could bring change in students' self-efficacy belief about extensive reading, and develop their reading capacity in the target language.

\subsection{Statement of the Problem}

Recently, Ethiopian Ministry of Education (MoE, 1994) emphasized on teaching of reading particularly in General Secondary and Preparatory Schools. This was because the ministry thought that English is required for entry into the tertiary level of education (MOE, 2004). The ministry, then, decided to empower the students in higher order reading skill(e.g. analyzing, synthesizing, summarizing, drawing conclusion, finding details) at this right level before they join the tertiary level. This decision of the ministry enables the students to be competent in the target language and can latter participate in the world of work. However, the students of preparatory schools in the country fail to meet this objective. This was perhaps because of students' misguided self-efficacy about reading and their lack of experiencing extensive reading. If students were positively self-efficacious, they would significantly develop their reading skill( Bandura, 1997). This implies that the more opportunities students practice extensive reading, the more likely they are to maintain positive self-efficacy belief toward reading. Different ideas have been said in relation to this in the introduction section of this study.

In addition, Adeline (2012) conducted an action research on 68 Taiwanese EFL freshmen students to promote their EFL inferential reading skills. Adeline (Ibid) used computerized dynamic assessment (C-DA) program which integrated mediation with assessment for the intervention. The result of written self reflection questions showed that students generated rich information and their meta-cognition in reading processes increased. T-test resul from pre and post inferential reading tests indicated that the participants scored significantly higher score on the posttest than on the pre-test in their inferential reading skill after the computerized mediation.

Similarly, Naeini (2014) conducted a study of DA and SLA on Indian Islamic Azad University students to see their development of EFL reading comprehension. Naeini(ibid) used Feuerstein's MLE and EFL Learners' Reading Comprehension. The One-way ANOVA results of the post reading comprehension test data analyses indicated that the experimental group reading comprehension was significantly improved than that of the control group because of the MLE intervention approach of DA. In Ethiopia, Abiy (2005) conducted a case study on grade 9 students, Ethiopia to see students' reading skill. Abiy, too, used Feuerstein's MLE, and the result portrayed that students' overall brainwave about reading was improved as a result of mediated learning.

However the above mentioned researches employed mediation, they merely focused on students' inferential reading, reading comprehension and reading skill respectively. They left students' self-efficacy belief untouched, which is a determinant variable for students learning not only in the reading but also in other skills and academic achievement. These researchers also did not see about students' extensive reading through which the students can build positive reading self-efficacy and, as a result of this, the students can develop their reading skill. Lastly, the researchers mentioned above did not have thought of about peer mediation. The current study focused on the variables missed in the studies of the above three indicated researchers. Also, from informal observation the current researcher made while he was teaching at preparatory schools, the EFL teachers seemed to fail to use extensive reading strategy during reading classroom. Hence, this study aimed to fill these gaps. 


\subsection{Objective of the Study}

\subsubsection{General Objective}

The general objective of the study was to investigate the effect of teacher and peer mediation on students' selfefficacy belief about their extensive reading practice

\subsubsection{Specific Objectives}

The specific objectives of the study were:

- $\quad$ To examine the extent in which teacher and peer mediation practice affects students' extensive reading practice.

- To investigate the degree in which teacher and peer mediation practice affects students' self-efficacy about reading.

\subsection{Research questions}

The study was to seek answer to the following research questions;

1. Does teacher and peer mediation affect students' extensive reading?

2. To what extent does teacher and peer mediation affect students self-efficacy belief about their reading?

\subsection{Research Hypotheses}

The following hypotheses were drawn based on the above research questions.

1. $\mathrm{H}_{0:}$ teacher and peer mediation does not have any significant effect on students' extensive reading.

2. $\mathrm{H}_{0 \text { : }}$ teacher and peer mediation does not have any significant effect on students' self-efficacy belief about reading.

\subsection{Significance of the Study}

The results of this study are expected to help different people related to the area by creating awareness on teacher and peer mediation practices and students' self-efficacy belief about extensive reading at preparatory school. The finding of this study enables the students to aware of that their self-efficacy belief would affect their extensive reading and the development of their reading skill positively or negatively.

Similarly, the finding helps EFL teachers to design mediated learning oriented teaching reading, and to use alternative strategies for teaching reading. The English textbook writers would be benefited from the finding for better and further insights to incorporate extensive reading practices into the students' textbook. The finding, also, usefully informs the Regional Education Bureau, Zone and Woreda (district) Education Officers to supply the schools extensive reading materials to be used by the students to the purpose. Lastly, the finding is expected to initiate academicians to conduct further research in the arena.

\subsection{Scope of the Study}

To make this research manageable, this study was delimited to Asossa preparatory school school in Benishangul Gumuz Regional State, Ethiopia. In the same vein, the study was limited to EFL teachers and grade eleven English learning students. It was also limited to extensive reading and to students' self-efficacy belief though other reading strategy(intensive reading) and other students self-construct behaviors could be studied.

\section{Literature Review: Empirical evidence}

Bodies of empirical studies have been conducted on students' extensive reading and self-efficacy belief.

These empirical evidences on the aforesaid variables indicate that the variables have a significant impact on students learning reading. In addition, the findings seem to align with literature. However, there were exclusions. These variations occur due to the different methodologies used, the sample sizes taken, variables, method of analysis applied, and the different environments within which the studies were undertaken. Some evidences, the first three related to ER and the last two pertinent to self-efficacy belief were presented hereunder.

In order to see how ER was to the Japanese freshmen students, Robb (2001) conducted an exploratory study.He observed that the students were benefited from ER. These benefits as Robb (ibid) reported was an increase in students' reading comprehension level, speed, reading vocabulary and grammatical structure. The result also reported that students obtained better reading habits. Robb's study was consistent with Iwahori's (2008) study on Japanese secondary EFL learners (increased their reading rate), Horst's ( 2005) study on Canadian adults ESL learners (increase their vocabulary knowledge).

Arias (2009) made an attempt to see the effects of ER on Colombia students. Arias (ibid) provided the group of students under the study with as many and variety of books as possible for reading. The students were also allowed to select the book for their reading. Finally, the study could have three main findings. The one was, students' motivations were increased because of their involvement in self-selected readings. The other was, their reading habit was changed as a result of the amount of readings they did. The last one was, they could make written reports of their readings. The result also reported that the students' vocabulary level was increased through their 
writing and oral reports.

Joseph Ponnia (2009) conducted a study to determine the effects of ER on grammatical proficiency by comparing the performance of readers and non-readers. The result of the study reports that those who have a pleasure reading (ER in this case) habits easily out performed non-readers on test of grammar.

Similarly, different studies were conducted regarding students' self-efficacy belief. Kargar and Zamanian's (2014) study on 50 Iranian EFL advanced English learners to explore the relationship between students' selfefficacy and reading comprehension strategies used. The result of the study from the self-efficacy and reading comprehension strategies questionnaires data analysis revealed that there was a positive relationship between these variables.

Raoofi, Tan and Chan ( 2012) reviewed empirical studies. According to them, Mills, Pajares and Herron (2006) made survey on 95 college students who were learning French as a foreign language in the USA. The study found that there was a significant positive relationship between reading self-efficacy beliefs and reading proficiency.

Although many foreign studies have been conducted concerning ER and self-efficacy (belief), they related it to proficiency, performance, achievement and comprehension. Thus, as to my knowledge, no study has been conducted on effects of teacher and peer mediation on students' self-efficacy belief about their extensive reading in Ethiopia. This was another motivational force for me to conduct this study.

\section{Methodology}

The following were the methods and techniques used to collect data for the analysis purpose in this study.

\subsection{Research Design}

This study employed quasi-experimental research design. The design was used to measure the dependent variables before and after the intervention. It also allows conducting the intervention in the natural classroom rather than in the artificial laboratory, which in turn, helps the researcher to collect the live data. The students' extensive reading and self-efficacy belief about their reading were used as dependent variables, whereas teacher and peer mediation as combined independent variable. Two intact grade 11 classes were chosen and randomly assigned as experimental and control group to run the intervention.

\section{2. Participants}

Sixty grade 11 EFL students and two EFL teachers were participated in the study. The teachers were purposively selected among three EFL teachers. One of the teachers was assigned to control group while the assignment of the other teacher was to the experimental group. The teacher in the experimental group acted as a mediator while the one in the control group acted as a conventional teacher. The 60 participant students in the two intact classes were assigned as control $(\mathrm{N}=30)$ and experimental $(\mathrm{N}=30)$ group. Five students were selected from the experimental group based on the set criteria, and then, were assigned as peer mediators. The mediators (selected teacher and peers) were given training on mediated learning experience for three days before the intervention. The purpose of the training was to enhance mediators' awareness about and skills in mediating students' learning reading through mediation. The participants in both the control and the experimental groups attended reading classes for 8 weeks of the intervention. During the intervention sessions, the experimental group learned reading through mediation, while reading was taught to the control group through the conventional way (non- mediation).

\subsection{Instruments}

The following two forms of instruments were employed in this study.

\subsection{Self-self efficacy Beliefs Questionnaire}

Teacher and peer mediators' extensive reading practice (PER) and students' self-efficacy beliefs (SSEB) questionnaires were adapted and modified from Bandura's (1997) and Oxford's SILL (1990) self-efficacy belief questionnaires. The purpose of the questionnaires was to collect data on how mediators practiced extensive reading strategy and what self-efficacy belief the students held about their extensive reading before and after the intervention. All the items were constructed in positive statements.

Items were rated on a five-point Likert scale ranging from " always(5) to never(1) for the practice part, while "strongly agree"(5) to "strongly disagree" (1) for belief part. SPSS 20 was run to check internal consistency of the items. The Crombach's alpha reliability coefficient was found to be .79 and .81 for the practice and belief respectively both being greater than .70 (Cohen, Manion \& Morison, 2007) indicate accepted degree of reliability.

\subsection{Reading Tests}

The researcher developed and administered the same reading tests to the two group students. The tests were developed align with IELT and TOEFL standard tests (2012). The tests consisted of equal items and contents. The pretest was used to examine the students' current reading skill ability and to see the homogeneity of the two groups of students. Whereas the post test was used to compare the score with that of the pretest in order to see whether 
or not mediators' ER practice and students' self-efficacy belief about ER was improved because of the intervention

\section{Data Collection Procedures}

First, the pre-intervention questionnaire was administered to both group students by the sampled EFL teachers during their English class in the presence and close supervision of the researcher. Completing the questionnaire lasted 18 minutes. Second, the pre-test was administered to both groups three days before the beginning of the intervention. It lasted in 41 minutes. Finally, the post-questionnaire and post reading tests were administered to both groups on the fourth day after the completion of the intervention. Completing the questionnaire and the test took 15 and 51 minutes respectively. All the questionnaire and test papers were collected at students' seat, therefore, the return rate was complete $(100 \%)$. The researcher corrected and scored the feedbacks and used it in the analysis.

\section{Data Analysis and Procedures}

To analyze both descriptive and inferential statistics of the data, SPSS version 20 was employed and the significance level was set at $\mathrm{p}<.05$. First, normality of teacher and peer' (mediators) practice of extensive reading (PER) and students' self-efficacy belief (SSEB) about extensive reading questionnaire data set was checked. The mean for both questionnaire data was computed by adding up students' scores associated with a point value of each item and dividing by the total item of the subscale to create summated mean, and then, grand mean was calculated. Next, reading tests were scored by assigning one score to each correct answer and all scores were then added up to compute the total score for every student. Then, independent sample $t$-test was computed to determine the homogeneity of the two groups in terms of the issues used in the questionnaire and reading test prior to the intervention. Paired sample t-test was run to ascertain whether or not significant improvement resulted on the preand post-questionnaire and reading test means within the individual group (control and experimental) after the intervention was completed. Finally, effect size statistics was employed to measure the magnitude of the observed mean difference between the groups. Cohen (1988) as cited in Pallant(2007) interpreted the values of effect size as $.01=$ small effect, $.06=$ moderate effect and .14 large effect. These were used in this study to the purpose.

\section{Results}

The quasi-experimental design of this study with questionnaire, pre-test, post-test, control group, experimental group and intervention yielded significant results. The results achieved were shown via tables.

\subsection{Self-efficacy Beliefs Questionnaire}

\section{Hypothesis 1}

$\mathrm{H}_{0 \text { : }}$ teacher and peer mediation does not have any significant effect on students' extensive reading.

To test the first research hypothesis, independent sample tests were applied. Then, mean comparison between the two groups on the two variables, ER and SEB, was made to the pre- intervention questionnaire data. Table 1 and 2 below summarize regarding this.

Table 1 Descriptive statistics of PER and SSEB between the two groups (Pre- intervention questionnaire) Group Statistic

\begin{tabular}{|c|c|c|r|r|r|l|}
\hline PER Vs SSEB & groups & \multicolumn{1}{|c|}{$\mathrm{N}$} & Mean & \multicolumn{1}{c|}{ SD } & Std.EM & GM \\
\hline & Cont & 30 & 3.73 & 1.080 & .19730 & \\
PER & Expl & 30 & 3.46 & .973 & .17768 & 3.59 \\
\hline SSEB & Cont & 30 & 4.06 & .639 & .11679 & \\
& Expl & 30 & 3.76 & .935 & .17075 & 3.91 \\
\hline
\end{tabular}

Key: $P E R=$ Extensive reading practice, SSEB $=$ Self-efficacy belief, $G M=$ Grand mean

Table 1 portrays that the summated mean scores and standard deviations of the two groups on the constructs (PER and SSEB) seem to be closer, the difference being 0.27 and 0.30 respectively before the intervention. However, the grand mean shows the existence of mean difference. To check whether or not this difference was statistically significant, it was worth computing independent samples test. This is shown in Table 2 below.

Table 2 Mean comparison between the two groups on ER and SEB

\begin{tabular}{|c|c|c|c|c|c|c|c|c|}
\hline \multirow{2}{*}{$\begin{array}{l}\text { PER } \\
\text { Vs } \\
\text { SSEB }\end{array}$} & \multirow{2}{*}{$\begin{array}{l}\text { Equal } \\
\text { variance }\end{array}$} & \multicolumn{2}{|c|}{$\begin{array}{l}\text { Levene's Test for Equality of } \\
\text { Variances }\end{array}$} & \multicolumn{5}{|c|}{ t-test for Equality of Means } \\
\hline & & $\mathrm{F}$ & Sig. & $\mathrm{t}$ & df & $\begin{array}{l}\text { Sig.(2- } \\
\text { t) }\end{array}$ & MD & Std. E \\
\hline $\begin{array}{l}\text { PER } \\
\text { SSEB }\end{array}$ & $\begin{array}{c}\text { assumed } \\
\text { not assumed }\end{array}$ & 452 & .504 & $\begin{array}{l}1.004 \\
1.450\end{array}$ & $\begin{array}{l}58 \\
58\end{array}$ & $\begin{array}{l}.319 \\
.153\end{array}$ & .2666 & .26551 \\
\hline
\end{tabular}

Key: $P E R=$ practice of extensive reading ( by teacher and peer mediators), SSEB = students' self-efficacy belief

Independent samples t-test was conducted to evaluate the existing EFL teachers' practice of using extensive reading (PER) strategy during teaching. In the same vein, this test was run to see the self-efficacy belief the two group students held (SSEB) about extensive reading prior to the intervention. 
Results in Table 2 proved that there was no statistically significant difference in PER mean scores for control $(M=3.73, S D=1.080)$ and for experimental $(M=3.46, S D=.973 ; \mathrm{t}(58)=-1.004, \mathrm{p}>.05$ (two-tailed) ; and in SSEB mean scores for control $(M=4.06, S D=.639)$ and for experimental $(M=3.76, S D=.935 ; \mathrm{t}(58)=.1 .450$, $\mathrm{p}>.05$ (two-tailed). The Etta square statistic for PER (.01) and SSEB (.03) indicated small effect size. The sig. (two-tailed) values of the constructs are greater than the cut off alpha level, .05. Therefore, the assumptions were met, the null hypothesis was retained, the alternative hypothesis was rejected and the students were homogenous before the intervention.

Next, the mean comparison between PER and SSEB was made on pre and post intervention questionnaire within the control group students using paired sample t-test as presented in Table 3.

Table 3. Mean comparison of PER and SSEB within the control group on pre - post questionnaire Paired Samples Test

\begin{tabular}{|l|l|l|l|l|l|l|l|l|}
\hline \multirow{2}{*}{ variables } & \multicolumn{5}{|c|}{ Paired Differences } & $\mathrm{t}$ & $\mathrm{d}$ & \multirow{2}{*}{ Sig. (2taile } \\
\cline { 2 - 10 } & $\mathrm{M}$ & Std. D & Std. Er M & \multicolumn{2}{|c|}{$95 \%$ CI } & & & \\
\hline Pair1 PER & -.03333 & .76489 & .13965 & -.31895 & .25228 & -.239 & 29 & .813 \\
\hline Pair2 SSEB & .20000 & .71438 & .13043 & -.06676 & .46676 & 1.533 & 29 & .136 \\
\hline
\end{tabular}

As can be seen in Table 3 above, the paired sample t-test result proved that there was no a statistically significant mean difference within the control group students for PER in pre-intervention questionnaire $(\mathrm{M}=3.73$, $\mathrm{SD}=1.080)$ and post intervention questionnaire $(\mathrm{M}=3.76, \mathrm{SD}=.817), t(29)=-.239, \mathrm{p}>.05$ (two-tailed). The mean increase in post-intervention questionnaire scores was -.03333 (95\% CI: -.31895 to .25228$)$ or $95 \%$ CI of the mean $=-.03333 \pm 0.5$. The eta squared statistic $(.001)$ indicated a very small effect size. The result also proved that there was no statistically significant mean difference from pre-intervention $(\mathrm{M}=4.06, \mathrm{SD}=.639)$ to post intervention $(\mathrm{M}=3.8667, \mathrm{SD}=.819)$, with mean decrease $.200, t(29)=1.533, \mathrm{p}>.05$ (two-tailed) for SSEB. The eta squared statistic (.07) relatively indicated large effect size. As a result, the null hypothesis was retained.

Similarly, paired sample t-test was computed to see whether or not teacher and peer mediation brought significant increase in its use of ER strategy, and to see to what extent students' self-efficacy belief raised towards extensive reading. Table 4 presented in this regard hereunder.

Table 4. Paired means difference within experimental group on pre - post questionnaire Paired Samples Statistics

\begin{tabular}{|lc|c|r|r|r|r|}
\hline \multirow{2}{*}{} & \multirow{2}{*}{ variables } & \multicolumn{3}{|c|}{ Paired difference } & \multicolumn{3}{c|}{ t-test for equality of means } \\
\cline { 2 - 7 } & Mean & \multicolumn{1}{c|}{ SD } & \multicolumn{1}{c|}{$\mathrm{t}$} & \multicolumn{1}{c|}{ sf } & \multicolumn{1}{c|}{ ig } \\
\hline Pair 1 & PER & -.66667 & .92227 & -3.959 & 29 & .000 \\
Pair 2 & SSEB & -.46667 & .62881 & -4.065 & 29 & .000 \\
\hline
\end{tabular}

The paired sample t-test result in Table 4 depicts that there was a statistically significant difference within the experimental group students on both variables. There was statistically significant increase on pre-post intervention questionnaire scores. The significant improvement was obtained at $t(29)=-3.959, p<.05$ (two-tailed) for PER and $t(29)=-4.065, p<.05$ (two-tailed) for SSEB. Therefore, significant change was observed in both the variables after the intervention. Thus, the null hypothesis was rejected and the alternative one was retained.

Next, the correlations test was applied for PER and SSEB as seen in Table 5 below.

Table 5. Relationship between extensive reading practice and self-efficacy belief

\begin{tabular}{|c|c|c|}
\hline \multicolumn{3}{|c|}{ Correlations } \\
\hline & 1 & 2 \\
\hline 1 PER & --- & \\
\hline $2 \mathrm{SSE}$ & .408 & \\
\hline
\end{tabular}

**. Correlation is significant at the 0.01 level (2-tailed).

The Pearson product-moment correlation coefficient was computed to see the relationship between the two variables, i.e., PER and SSEB. There was a statistically significant positive correlation between the teacher and peers' mediating students' learning reading using extensive reading strategy and students' self-efficacy belief about reading, $r=.408, N=58, p<.01$, with low level of extensive reading strategy use associated with high level of students' perceived self- efficacy belief about reading. The strength of correlation coefficient was medium $(r$ $=.30-.49$ ) Cohen (1988) as cited in Pallant (2007). Based on the coefficient value, $r=.408$, the two variables shared $16.64 \%$ variance. The result implies that students who hold perceived self-efficacy belief about extensive reading would likely develop their reading skill.

Below is the presentation of inferential analysis result of students' reading test score.

Hypothesis 2

$\mathrm{H}_{0 \text { : }}$ teacher and peer mediation does not have any significant effect on students' self-efficacy belief about reading 
Table 6. Independent samples t-test of the two groups on the pretest and posttest

In answering the second research question (or to test hypothesis 2), independent sample tests were applied as followed.

Table 6a. Levenes test for equality of variances (Pre-intervention reading test)

\begin{tabular}{|l|c|c|c|}
\hline \multirow{2}{*}{ Test } & & \multicolumn{2}{|c|}{ Levene's Test for Equality of Variances } \\
\cline { 3 - 4 } pretest & Equal variances & $\mathrm{F}$ & Sig. \\
\cline { 2 - 4 } & assumed & .108 & .744 \\
\hline
\end{tabular}

Both the control and the experimental group students were given reading test prior to the intervention to evaluate their existing ability in reading. Their mean scores (13.8667 and13.6667) respectively were closer to each other. In this regard, Table 6 a above depicted that the sig. value for students' initial reading ability before the intervention was .744. This sig. value was greater than the cut point of the alpha level, .05. Therefore, it can be assumed that the variances were equal. This result has lead the researcher to make the next test (see Table 6b below)

Table 6b. Levenes test for equality of means (Pre-intervention reading test)

\begin{tabular}{|l|l|c|c|c|c|c|}
\hline \multirow{2}{*}{ Test } & Equal variances & \multicolumn{6}{|c|}{ t-test for Equality of Means } \\
\cline { 3 - 7 } & & $\mathrm{t}$ & $\mathrm{df}$ & Sig.(2-tailed & $\mathrm{M} \mathrm{d} / \mathrm{c}$ & Std.EM \\
\hline \multirow{2}{*}{ pretest } & assumed & .529 & 58 & .598 & .20000 & .37773 \\
\cline { 2 - 7 } & not assumed & \multicolumn{6}{|c}{}
\end{tabular}

Based on the result in Table 5a above, it was possible to test the hypothesis using the Equal Variances Assumed row of the $t$-test in Table 5b. This provided the $t$-value $(t=.529)$, the degrees of freedom $(d f=58)$, and $\mathrm{sig}$. $(2$-tailed $)=.598$, which was greater than .05 . Hence, there was no significant difference between the two groups current reading ability before the intervention.

Table 7. Independent samples t-test of the two groups on the posttest

\begin{tabular}{|l|l|l|l|l|l|l|l|}
\hline Group & $\mathrm{N}$ & $\mathrm{M}$ & $\mathrm{SD}$ & $\mathrm{t}$ & $\mathrm{df}$ & $\mathrm{sig}$ & $\mathrm{d}$ \\
\hline control & 30 & 14.13 & 1.569 & & & & \\
\cline { 1 - 4 } Experimental & 30 & 23.90 & 2.186 & -19.871 & 58 & .000 & .89 \\
\hline Group mean difference & -9.77 & -.617 & \multicolumn{7}{|l}{} \\
\hline
\end{tabular}

Key: $d=$ Cohen's d effect size

Table 6 above portrays that there was considerable mean difference between the two participant groups on post reading test results. The experimental group surpasses the control group mean score on the post test. One can easily calculate the mean difference as $\mathbf{- 9 . 7 7}$. Therefore, the independent samples t-test proved that there was statistically significant difference between the mean score of post test for control group $(\mathrm{M}=14.13, \mathrm{SD}=1.569)$ and for experimental $(\mathrm{M}=23.90, \mathrm{SD}=2.186), \mathrm{t}(58)=-19.871, \mathrm{p}<0.05$ (two-tailed). The eta squared statistic (.89) indicated very large effect size. It can be deduced that teacher and peer mediation brought a significant change to students' self-efficacy belief and their reading skill development by exposure to extensive reading.

Table 8. Paired samples test of mean differences within the two groups on Pre-posttest

Paired Samples Test

\begin{tabular}{|ll|l|l|l|l|c|}
\hline & & \multicolumn{3}{|l|}{ Paired Differences } & \multicolumn{2}{l|}{ t-test for significance } \\
\cline { 3 - 7 } & & $\mathrm{M}$ & $\mathrm{SD}$ & $\mathrm{t}$ & $\mathrm{df}$ & $\mathrm{sig}$ \\
\hline Pair1 & cont. & -.26667 & 1.17248 & -1.246 & 29 & .223 \\
\hline Pair2 & Expl. & -10.23333 & 2.56882 & -21.819 & 29 & .000 \\
\hline
\end{tabular}

A paired-samples t-test was conducted to evaluate the impact of the intervention, through teacher and peer mediation, on students' pre-post EFL reading skill test scores. Table 7 above indicated that very small mean increase was observed for control group $(\mathrm{M}=$-.26667) from pre to post test. Also the sig. value for the pair was insignificant (.223). On the contrary, in the same table, very large paired difference, increasing, was observed for experimental group $(\mathrm{M}=-10.23333)$, the sig. value being less than the alpha level, 0.05 .

Generally, paired-samples t-test reports that there was no a statistically significant difference within the control group students on pre-post test scores, $\mathrm{t}(58)=-1.246, \mathrm{p}>.05$ (two-tailed). In the same table, it was depicted that there was a statistically significant difference within the experimental group students on the pre-post test scores, $\mathrm{t}(58)=-21.819, \mathrm{p}<.05$ (two-tailed). The eta squared statistic (.05) for control group and (.94) for experimental group indicated relatively medium and a very large effect size respectively.

\section{Discussions, conclusion and recommendations}

The findings sought, conclusions drawn and recommendations made were presented hereunder.

\subsection{Discussions}

1. The results of pre-intervention questionnaire data showed that the teacher and peer mediation practice of employing extensive reading in both control and experimental group to mediate students' learning reading was 
less than it was deserved. On the contrary, the grand mean (3.91) showed that students have had higher selfefficacy belief about extensive reading. The finding also vividly put that there was no significant difference between both group EFL teachers' extensive reading practice and students' self-efficacy belief about extensive reading during the pre-intervention phase.

2. The pre-post intervention questionnaire result found out that the control group English teacher's practice of extensive reading and the students' self-efficacy belief about extensive reading was found to be mismatched throughout the intervention time. Insignificant mean difference was seen between these variables on pre and post intervention questionnaire mean scores. From the finding, the reason could be suggested as that the teacher fail to employ extensive reading strategy to mediate the students. Also, the conventional teacher placed less emphasis on extensive reading, which may predict $\mathrm{s}$ /he prioritizes intensive reading. On the contrary, students held positive self-efficacy belief about extensive reading thought that it helps them to raise their need for reading in general. This finding agrees with what the literature notes. Nuttal(1996) pointed out that it is difficult to be an effective reader(s) unless the habit and initiation of reading is developed from the early time of school age through extensive reading.

3. On the other hand, the finding of pre-post intervention questionnaire data from experimental group revealed that there was a statistically significant mean difference between the two constructs. This means that the mediators (teacher and peers) effectively employed extensive reading strategy and mediated students' learning reading during the intervention. The possible reason might be teacher and peer mediators appropriately used the mediation criteria as suggested by Feurestein $(1980 ; 1990)$. As a result, the students significantly engaged into extensive reading so that they build positive self-efficacy belief in themselves about it. Thus, the finding also suggests that the students would most likely improve their reading skill as a whole. This finding corroborates the finding on pre-post reading test in which the improvement was observed in the experimental group.

4. In addition, from both group students' pre-intervention reading test scores, it was found out that the EFL teachers' practice of extensive reading strategy use during teaching reading classes seemed to be low. The uniformity of both group EFL teachers in employing extensive reading strategy had kept the students to stay with the self-efficacy belief they already held about extensive reading before the intervention. This finding confirms Cohen, Manion and Morison's (2000) idea on test. They stated that two comparison groups have the same test result unless the treatment is given to either group.

5. However, the finding of the paired sample t-test showed that there was increase in mean scores from pre to post test for the two groups. Though mean increase was observed, it was found to be insignificant for control group, sig. $223=\mathrm{p}>.05$. Further, the finding revealed that there was a significant difference within the experimental group on pre-post test scores, sig. $000=p<.05$. This finding substantiates the literature that notes positive selfefficacious students are successful on accomplishing reading tasks and improve their skill while those who held negative self-efficacy belief are not ( Bandura, 1997).

\subsection{Conclusion}

Based on the findings mentioned earlier, the following conclusions were drawn.

1. It was concluded that EFL teacher and peer mediation was determinant factor to effectively practice extensive reading during teaching reading and to satisfy students' self-efficacy belief about their extensive reading.

2. The grand mean observed from pre-intervention questionnaire suggested that there was discrepancy between the EFL teachers' practice of extensive reading during teaching reading and the self-efficacy belief the students had already held about their extensive reading. However, this disparity was solved after the intervention because of the intervention.

3. Students' active involvement in extensive reading considerably raised their self-efficacy belief towards reading in general and to extensive reading in particular after the post intervention phase.

4. The comparison between the control and experimental group students on post-questionnaire response and postreading test scores vividly concluded that the way the students were taught affected their self-efficacy belief about their extensive reading.

5. The study concluded that extensive reading was the driving force for the students to raise the self-efficacy belief that they already held about it and to develop their reading skill. Also, the mediators' effective practice in employing extensive reading in the class could develop positive self-efficacy belief in students, and then, the students enthusiastically love learning reading as a whole.

6. The intervention was effective and achieved the objective of the study.

\subsection{Recommendation}

Based on the findings and the conclusions, the recommendations have been made

$>$ The discrepancy observed between EFL teachers practice of extensive reading and students' perceived self-efficacy belief disfavors students' feeling about their extensive reading. Thus, it is advisable if the EFL teachers' practice of extensive reading meets the students' self-efficacy belief about it. 
$>$ since peer mediation provide the students with tension free and passionate support, curriculum developers need to upgrade the currently 1 to 5 students group to peer tutor.

$>$ The Ministry of Education, Region Education Bureau and Zone Education Office need to publish, buy and supply extensive reading materials to the preparatory schools.

\section{Reference}

Alahdadi, A. and Ghanizadeh, A. 2017. The dynamic interplay among EFL learners' ambiguity tolerance, adaptability, cultural intelligence, learning approach, and language achievement: Iranian Journal of Language Teaching Research 5(1), 37-50, Urmia University.

Bandura, A. 1997. Self-efficacy: The Exercise of Control, W.H. Freeman and Company,New York, NY.

Boakye, N.2015. The relationship between self-efficacy and reading proficiency of first- year students: An exploratory study, Reading \& Writing 6(1), 1-9. http://www.rw.org.za doi10.4102/rw.v6i1.52

Brittany, C. 2017. "Reading Comprehension and Self Efficacy" All Capstone Projects. http://opus.govst.edu/capstones/283.

Cheng. X, Samuel, M. and Hua, C.2012. Evaluation on EFL teacher roles from the perspective of mediation: Case studies of china's secondary school classroom practices. International Review of Social Sciences and Humanities 3 (1), 117-134.

Cohen, L., Manion,L. and Morrison, K.2000. Research Methods in Education (5 $5^{\text {th }}$ ed). Great Britain.

Cohen, L., Manion,L. and Morrison, K.2007. Research Methods in Education ( $6^{\text {th }}$ ed). Routledge,Taylor and Francis e-Library, 2007. London and New York.

Dorkchandra, D. 2010. Enhancing English reading comprehension through a text structure reading strategy call program (Doctoral Thesis). Suranaree University of Technology.

Feuerstein, P. S. Klein and A. J. Tannenbaum (Eds.), Mediated Learning Experience: Theoretical, Psychosocial and Learning Implications. London:Freund.

Feuerstein, R. (1990). The theory of structural modifiability, in B. Presseisen (Ed.),Learning and Thinking Styles: Classroom Interaction. Washington, DC: National Education Association.

Feuerstein, R. and Feuerstein, S. 1991. Mediated learning experience: A theoretical review, in R.

Feuerstein, R.1980.Instrumental enrichment and the concept of cognitive modifiability, University Park Press, Baltimor.

Gangloff, B. and Mazilescu, C. 2017. Normative characteristics of perceived self-efficacy. Social Sciences, 6(4), $1-18$.

Hamral, A. \& Syatriana, E. 2012. A model of reading teaching for university EFL students: Need analysis and model design. English Language Teaching, 5(10), 1-11. Retrieved on 12/10/2018 from http://dx.doi.org/10.5539/elt.v5n10p1.

Hasan, B. Z. M., Hossain, B. T. and Islam, A. (2014). Factors affecting self-efficacy towards academic performance: A study on polytechnic students in Malaysia. Advances in Environmental Biology, 8(9), 695705.Retrieved on 07/12/2018 from http://www.aensiweb.com/aeb.html.

Hermida, J. 2009. The importance of teaching academic reading skills in first-year university courses. The International Journal of Research and Review, 3, 20 -30.

Horst, M. (2005). Learning L2 vocabulary through extensive reading: A measurement study. The Canadian Modern Language Review, 61, 355-382.

Iwahori, Y. (2008). Developing reading fluency: A study of extensive reading in EFL. Reading in a Foreign Language, 20/1.

Jarrahzade Z.2014. Promoting EFL Learners' Reading Comprehension Skills through Dynamic Assessment Using Guthke's Lerntest Approach. International Journal of Foreign

Kargar.M and and Zamanian.M. (2014). The relationship between self-efficacy and reading comprehension strategies used by iranian male and female EFL learners. International Journal of Language Learning and Applied Linguistics World, 7(2), 313-325.

Katz, S. 2006. Self-efficacy of college students to learn English: Reading comprehension activities as a result of differential reflection and skill training. Shaanan College Annual. Retrieved on 19/05/2018 from https://scholar.google.com/.Language Teaching \& Research, 3( 5), 1-24. language Education, vol.9:12. Retrieved Desember 16, 2018

Ministry of Education (MoE) .1994. Ethiopian education and training policy. unpublished policy document. Addis Ababa: Ethiopia.

Naseri, M. and Zaferanieh, E. 2012.The Relationship between Reading Self-efficacy Beliefs, Reading Strategy Use and Reading Comprehension Level of Iranian EFL Learners. World Journal of Education, 2(2), 64 -75. Retrieved on 21/10/2018 from http://dx.doi.org/10.5430/wje.v2n2p64.

Overett, J and Donald, D. 1998. Paired reading: effects of a parent involvement programme in a disadvantaged community in South Africa. British Journal of Educational Psychology, 68,347-356. The British 
Psychological Society, Great Britain

Oxford, R. 1990. Language Learning Strategies: What Every Teacher Should Know. New York: Newbury House/Harper \& Row. Now Boston: Heinle \& Heinle.

Pajares, F. 1996. Self-efficacy beliefs in academic settings. Review of Educational Research, 66, 543-578.

Pajares, F. 2002. Overview of Social Cognitive Theory and of Self-efficacy, available at: www. emory.edu/EDUCATION/MFP/eff.html R. Feuerstein, P. S. Klein \& A. J. Tannenbaum (Eds.), Mediated Learning Experience: Theoretical,Psychosocial and Learning Implications. London:Freund.

Ponniah,R. Joseph (2009). The robustness of Free Reading in Second and Foreign

Rao, Z. (nd). Approaches to Learning and Reading Strategy Use of Bilingual Primary School Pupils. National Institute of Education Nanyang Technological University Singapore.

Raoofi. S, Tan.B.H \& Chan.S.H.( 2012 ). . Self-efficacy in Second/Foreign Language Learning Contexts. English Language Teaching; 5(11), 60-73.

Robb, T. N. (2001). Extensive reading for Japanese English majors. In J. Murphy \& P. Byrd (Eds.),Understanding the courses we teach. Local perspectives on English language teaching (pp. 218-235). Ann Arbor, MI: The University of Michigan Press.

Ruíz, N., \& Arias, G. (2009). Reading beyond the classroom: The effects of extensive reading at USTA, Tunja. HOW A Colombian Journal for Teachers of English, 16, 71-91.

Tait, H. and Entwistle, N. J. 1996. Identifying students at risk through ineffective study strategies. HigherEducation, 31, 99-118.

Tait, H., Entwistle, N. J. and Velda M. 2013. Identifying students at risk through ineffective study strategies. Report of the development and use of the inventories.

Tobing, I.R.A. 2013. The relationship between reading strategies and self-efficacy with reading comprehension high school students in Indonesia. Doctoral Dissertation. Kansas University. University Park Press, Baltimor.

Vygotsky, L. S. 1986. Thought and language (A. Kozulin, Trans.). Cambridge, MA: MIT Press. (Original work published 1934).

Vygotsky, L. S.1978. Mind in society: The development of higher psychological processes. Cambridge, MA: Harvard University Press.

Waleff, M.L. 2010.The relationship between mastery orientation goals, student self-efficacy for reading achievement in intermediate level learners in a rural district'. Walden University, Minneapolis. 